\title{
In Vivo Screening for Analgesic and Anti-Inflammatory Activities of Syngonium podophyllum L.: A Remarkable Herbal Medicine
}

\author{
Md. Sarwar Hossain ${ }^{1}$, Md. Sahab Uddin ${ }^{2^{*}}$, Md. Tanvir Kabir ${ }^{3}$, \\ Shammi Akhter ${ }^{2}$, Srijan Goswami ${ }^{4}$, Abdullah Al Mamun ${ }^{2}$, \\ Oscar Herrera-Calderon ${ }^{5}$, Md. Asaduzzaman ${ }^{2}$ and Mohamed M. Abdel-Daim ${ }^{6}$ \\ ${ }^{1}$ School of Biosciences and Veterinary Medicine, University of Camerino, Camerino, MC, Italy. \\ ${ }^{2}$ Department of Pharmacy, Southeast University, Dhaka, Bangladesh. \\ ${ }^{3}$ Department of Pharmacy, BRAC University, Dhaka, Bangladesh. \\ ${ }^{4}$ Department of Molecular Biology and Immunology, Institute of Genetic Engineering, Kolkata, India. \\ ${ }^{5}$ Academic Department of Pharmaceutical Sciences, Faculty of Pharmacy and Biochemistry, \\ Universidad Nacional San Luis Gonzaga de Ica, Ica, Peru. \\ ${ }^{6}$ Department of Pharmacology, Faculty of Veterinary Medicine, Suez Canal University,
}

Ismailia, Egypt.

\section{Authors' contributions}

This work was carried out in collaboration between all authors. Authors MSU and MA designed the study, wrote the protocol and managed the analyses of the study. Authors MSH, MSU, MTK and SA performed the laboratory tests and prepared the draft of the manuscript. Authors SG, AAM and OHC participated in literature review and statistical analysis. Author MMAD reviewed the scientific contents of the manuscript. All authors read and approved the final manuscript.

Article Information

DOI: $10.9734 / A R R B / 2017 / 35692$ Editor(s):

(1) Anjoo Kamboj, Chandigarh College of Pharmacy, Landran, Mohali, India. (2) George Perry, Dean and Professor of Biology, University of Texas at San Antonio, USA. Reviewers:

(1) Esraa Ashraf Ahmed ElHawary, Ain Shams University, Egypt. (2) Arun Kumar, Hindu Post Graduate College, India. Complete Peer review History: http://www.sciencedomain.org/review-history/20787

Original Research Article

Received $25^{\text {th }}$ July 2017 Accepted 23 ${ }^{\text {rd }}$ August 2017 Published $2^{\text {nd }}$ September 2017

\section{ABSTRACT}

Aims: Algesia and inflammation are strongly connected with several pathological conditions. Searching for natural healing agents with a better safety profile for the treatment of these conditions are ongoing due to multiple unwanted effects associated with synthetic pharmaceuticals. Therefore the purpose of this study was to analyse the analgesic and anti-inflammatory activities of the 
Syngonium podophyllum (S. podophyllum) L. leaves.

Study Design: The fresh leaves of S. podophyllum L. were extracted with methanol (CME) followed by fractionation using n-hexane (NHF), chloroform (CLF), ethyl acetate (EAF) and water (AQF). Then analgesic and anti-inflammatory activities of crude extract and its fractions were determined using standard methods.

Place and Duration of Study: Department of Pharmacy, Southeast University, Dhaka, Bangladesh, from January to April 2017.

Methodology: Tail immersion and acetic acid induced writhing tests were used for the determination of analgesic activity, whereas anti-inflammatory activity was determined by carrageenan induced paw edema test.

Results: Among the plant extract and its fractions, CME showed significantly higher $(60.53 \%$, $\mathrm{P}<0.001)$ analgesic activity in the tail immersion test. In the acetic acid-induced writhing test, CME also showed marked inhibition $(59.58 \%, P<0.01)$ of algesia with respect to remaining fractions. CME demonstrated significant $(71.11 \%, \mathrm{P}<0.001)$ anti-inflammatory effect than the other fractions in carrageenan induced paw edema test.

Conclusion: The denouements of this study showed that the crude extracts of the S. podophyllum L. leaf have an effective analgesic, anti-inflammatory activities and thereby possess an excellent source of natural agents which could be developed in the treatment of diseases related to algesia and inflammation.

Keywords: Syngonium podophyllum; algesia; inflammation; safety profile; synthetic pharmaceutical.

\section{ABBREVIATIONS}

S. podophyllum: Syngonium podophyllum; CME: Crude methanol extract; NHF: n-hexane fraction; CLF: Chloroform fraction; EAF: Ethyl acetate fraction; AQF: Aqueous fraction; IASP: International Association for the Study of Pain; NSAIDs: Non-steroidal anti-inflammatory drugs; Dic-Na: Diclofenacsodium; Ind: Indomethacin; b.w.: Body weight; ICDDR,B: International Centre for Diarrheal Disease and Research, Bangladesh; NIH: National Institutes of Health; OECD: Organisation for Economic Cooperation and Development.

\section{INTRODUCTION}

The algesia and inflammation are multidimensional experience that is essential for the maintenance and preservation of an individual [1]. Pain is a specific enteroceptive sensation that involves dedicated subsets of peripheral and central neurons [2]. According to the International Association for the Study of Pain (IASP), pain is an unpleasant sensory and emotional experience associated with actual or potential tissue damage, or described in term of such damage [3]. Under normal circumstances, primary afferent pain fibres activate particular central pathways that engage protective mechanisms at several functional levels such as autonomic, homeostatic, motoric, behavioural and mnemonic [4]. However, injury or disease can alter the balance of this system and result in persistent, pathological pain. Inflammation is a normal, protective response to tissue injury that involves immune cells, blood vessels and molecular mediators. It is such kind of disorder that involved in localized increases of the number of leukocytes, and different complex mediator molecules [5]. Inflammation is the body's effort to inactivate or destroy invading organisms, remove irritants and set the stage for tissue repair [6]. When healing is complete, the inflammatory process usually abates [7]. However, inappropriate activation of our immune system can result in inflammation leading to rheumatoid arthritis [8]. For treatment of algesia and inflammation there are numerous synthetic pharmaceuticals, but most of them are precarious [9].

Medicinal plants serve as an important area of interest for natural analgesic and antiinflammatory agents [10]. The uses of different plants to treat or cure numerous diseases are reexplored field for the current research [11]. It plays a vital role in the development of pharmaceuticals and in the management of various types of diseases [12,13]. Medicinal plants were and are still now one of the important sources of modern medicine [14]. There are long known histories in traditional or folk medicine that have herbal and natural products [15]. These medicines are safer and more economical from others and sometimes can be used as an alternative of the modern synthetic drug [16-19]. Prostaglandins are substances that are present in everywhere that indicate cell and tissue 
response that is involved in inflammation [20]. It is believed that medicinal plants are an important source of different new chemical substances with remarkable therapeutic effects [21,22]. Medicinal plants have been used as analgesic and antiinflammatory agents since the antediluvian era [23]. Now a day's, non-narcotics such as nonsteroidal anti-inflammatory drugs (NSAIDs) and narcotics are the most famous and important classes of pain and inflammation remover or killer, however they have high risk of various side effects like renal, hepatic and gastrointestinal complications [24,25].

The plant, Syngonium podophyllum (S. podophyllum) L. belongs to the family Araceae has large leaves in the adult form and is deeply lobed [26]. The species is native to a wide region of Latin America from Mexico to Bolivia and naturalized in the West Indies, Florida, Texas, Hawaii, and other places [27]. S. podophyllum L. leaf is used against dry skin, fungal infection, sore, itching, rashes and bruises [24,26,28-30]. Leaves and bark of this plant are traditionally employed in the local folk medicine of Belize for their wound healing properties, whereas the leaf tincture is used to treat rheumatism, arthritis, pain and swelling [24,26,28-30].

Literature is silent about biochemical activities of $S$. podophyllum L. leaves. Hence the present study was conducted to evaluate the analgesic and anti-inflammatory activities of S. podophyllum L. leaves.

\section{MATERIALS AND METHODS}

\subsection{Chemicals and Drugs}

Methanol, n-hexane, ethyl acetate and chloroform were bought from Sigma-Aldrich, USA. Acetic acid and carrageenan were bought from Merck, Germany. Diclofenac-sodium (Dic$\mathrm{Na}$ ) and indomethacin (Ind) were obtained from Square Pharmaceuticals Ltd., Dhaka, Bangladesh.

\subsection{Collection and Identification of Plant Materials}

The leaves of the plant S. podophyllum L. were collected from Dhaka, Bangladesh in January 2016. The plant material was taxonomically identified by expert of Bangladesh National Herbarium, Mirpur, Dhaka, Bangladesh and a voucher specimen has been deposited in the herbarium for future reference. Accession number: DACB-38722 for S. podophyllum L.

\subsection{Drying and Grinding of Plant Materials}

The fresh leaves of $S$. podophyllum $L$. were then washed properly and sun dried for 7 days and finally dried in an oven at temperature not more than $50^{\circ} \mathrm{C}$ for better grinding. The dried leaves were ground into coarse powder by using a mechanical grinder and stored in an airtight container.

\subsection{Extraction and Fractionation of Plant Materials}

Powdered plant materials with a weight of $500 \mathrm{~g}$ were taken in an amber colored glass bottle and subjected to extraction by $1.5 \mathrm{~L}$ of $98 \%$ methanol for 7 days with occasional agitation. After the extraction process the extract was filtered through cotton and then through Whatman No.1 filters paper and was concentrated with a rotary evaporator under reduced pressure at $50^{\circ} \mathrm{C}$ temperature to give crude extract $(10.45 \mathrm{~g})$. This crude methanol extract (CME) was then fractionated, initially with n-hexane (NHF) followed by chloroform (CLF) then ethyl acetate (EAF) and finally by the help of water (AQF) according to the method of Kupchan with slight modification [31]. The methanol extract and its fractions were re-filtered and evaporated by rotary evaporator at low pressure at $50^{\circ} \mathrm{C}$ temperature to remove excess solvent and yielded NHF, $2.95 \mathrm{~g}$; CLF, $2.58 \mathrm{~g}$; EAF, $1.09 \mathrm{~g}$ and AQF $3.38 \mathrm{~g}$ extract respectively.

\subsection{Experimental Animals}

Swiss albino mice of either sex weighing around 25 to $35 \mathrm{~g}$ were collected from the Animal Resources Branch of International Centre for Diarrheal Disease and Research, Bangladesh (ICDDR,B) and used to evaluate analgesic activity. Wistar albino rats $(125-135 \mathrm{~g})$ of either sex were also collected from ICDDR,B and used to estimate anti-inflammatory activity. They were kept in standard environmental condition for 1 week for adaptation after their purchase and feed with ICDDR,B formulated rodent food and water. They were housed three per cage and were kept at constant room temperature $\left(25.0 \pm 3.0^{\circ} \mathrm{C}\right)$, humidity (35-60\%) and $12 \mathrm{hrs}$ light and $12 \mathrm{hrs}$ dark cycle. Execrates were removed from the cages on every day. The use and care of animals was followed according to the guide for laboratory animals of the National Institutes of Health (NIH) [32]. The experimental protocols were approved by the ethical committee of the Department of the Pharmacy, Southeast University, Dhaka, Bangladesh. 


\subsection{Acute Oral Toxicity Test}

The acute toxicity test was directed for $\mathrm{CME}$ and its four fractions, i.e. NHF, EAF, CLF and AQF. Four groups of animal of either sex $(n=6)$ were treated with various test doses, i.e. 250,500 and $1000 \mathrm{mg} / \mathrm{kg}$ b.w. orally. Animals were constantly noticed for any behavioral, neurological profile for next 24 hrs and 14 days for mortality. The acute toxicity study of the extracts was performed according to the guidelines of the Organisation for Economic Cooperation and Development (OECD) [33].

\subsection{Analgesic Activity}

\section{$\underline{\text { 2.7.1 Tail immersion test }}$}

In this test, the analgesic action was examined according to the method stated by Aydin et al., with slight modification [34]. Seventeen groups of six mice $(n=6)$ in each were selected for this study. Group 1 (control) received distilled water (10 $\mathrm{mL})$, and group 2 was treated with Dic-Na (30 mg/kg b.w.) as standard drug. Group 3, 4 and 5 were treated with $\mathrm{CME}$, group 6,7 and 8 were treated with AQF, group 9, 10 and 11 were treated with NHF, group 12, 13 and 14 were treated with EAF and group 15, 16 and 17 were treated with CLF. The test extract/fractions were administered orally in a dose of 50, 100 and 200 $\mathrm{mg} / \mathrm{kg}$ b.w. respectively to the test group's animal (i.e. group 3 to group 17). Pain reactions were induced by dipping the animal's tail $(2-5 \mathrm{~cm})$ in a pot of water maintained at $54 \pm 0.5^{\circ} \mathrm{C}$. The reading was taken after $30,60,120$ and $180 \mathrm{~min}$ of administration of the standard and test sample. The cut-off time, i.e. time of no response was put at $30 \mathrm{sec}$. The percentage of analgesic activity was calculated by using the following formula:

$$
\text { Analgesic activity }(\%)=\left(T_{a}-T_{b} / T_{b}\right) \times 100
$$

where $T_{b}$ is the average time in seconds to withdraw the tail out of water of control group and $\mathrm{T}_{\mathrm{a}}$ is the average time in seconds to withdraw the tail out of water of treated group (i.e. standard or extract/fractions).

\subsubsection{Acetic acid-induced writhing test}

In this test, the analgesic action was examined using acetic acid-induced writhing test according to the method stated by Koster et al. [35] with slight modification. Seventeen groups of six mice $(n=6)$ in each were selected for this study. Group 1 (control) received distilled water $(10 \mathrm{~mL})$, and group 2 was treated with drug Dic-Na (30 $\mathrm{mg} / \mathrm{kg}$ b.w.) as standard. Group 3, 4 and 5 were treated with CME, group 6, 7 and 8 were treated with AQF, group 9, 10 and 11 were treated with NHF, group 12, 13 and 14 were treated with EAF, and group 15, 16 and 17 were treated with CLF. The test extract/fractions were administered orally in a dose of 50, 100 and $200 \mathrm{mg} / \mathrm{kg} \mathrm{b.w.}$ respectively to the test group's animal (i.e. group 3 to group 17). After a gap of 30 min of the administration of the test extracts, all the groups of mice were given $0.7 \%$ aqueous acetic acid, in a dose of $1 \mathrm{~mL} / 100 \mathrm{~g} \mathrm{b.w}$. intraperitoneally. $5 \mathrm{~min}$ after administration of acetic acid the number of writhing produced in these animals were counted for next $10 \mathrm{~min}$. The percentage of protection was calculated by using the following formula:

Inhibition of writhing $(\%)=\left(W_{b}-W_{a}\right) / W_{b} \times 100$

where $W_{b}$ is the average writhing of control group and $W_{a}$ is the average writhing of treated group (i.e. standard or extract/fractions).

\subsection{Anti-inflammatory Activity}

\subsubsection{Carrageenan-induced hind paw edema test}

In this test, the anti-inflammatory action was examined using carrageenan-induced hind paw edema model according to the method stated by Winter et al., with slight modification [36]. Seventeen groups of six rats $(n=6)$ in each were selected for this study. Group 1 (control) received distilled water $(10 \mathrm{~mL})$, and group 2 was treated with drug, Ind (10 mg/kg b.w.) as standard. Group 3, 4 and 5 were treated with CME, group 6, 7 and 8 were treated with AQF, group 9, 10 and 11 were treated with NHF, group 12, 13 and 14 were treated with EAF, and group 15, 16 and 17 were treated with CLF. The test extract/fractions were administered orally in a dose of 50,100 and $200 \mathrm{mg} / \mathrm{kg}$ b.w. respectively to the test group's animal (i.e. group 3 to group 17). 30 min after administration of the respective drugs, all the animals were treated with $0.1 \mathrm{~mL}$ of $1 \%$ carrageenan in the sub planter region of left hind paw. Paw volume was measured by using digital plethysmometer before administration of carrageenan and after $30 \mathrm{~min}, 60 \mathrm{~min}, 120 \mathrm{~min}$ and $180 \mathrm{~min}$ intervals. The percentage of inhibition of paw edema was calculated by using the following formula:

Inhibition of paw edema $(\%)=\left(V_{b}-V_{a}\right) / V_{b} \times 100$

where, $V_{b}$ is the average paw edema of control group and $V_{a}$ is the average paw edema of treated group (i.e. standard or extract/fractions). 


\subsection{Statistical Analysis}

The experiments were carried out in triplicate and all the results were expressed as mean \pm SEM. The data in all the experiments were analyzed by one-way ANOVA followed by Dunnett's test using IBM SPSS Statistics 20 software. Microsoft Excel 2010 (Roselle, IL, USA) was also used for the statistical and graphical evaluations. The level of significance was considered at $\mathrm{P} \leq 0.05$ compared to control group.

\section{RESULTS}

\subsection{Determination of Acute Toxicity}

In the acute toxicity assay no deaths were observed during the period at the doses tested. At these doses, the animals showed no stereotypical symptoms associated with toxicity, such as convulsion, ataxia, diarrhea or increased diuresis which indicates low toxicity profile of plant extracts and its fractions.

\subsection{Determination of Analgesic Activity by Tail Immersion Test}

The reaction time of mice in tail immersion test is given in Table 1. In Fig. 1, percentage of analgesic activity is presented. The marked analgesic effects $(P<0.001)$ were observed at $180 \mathrm{~min}$ at highest dose of CME compared to remaining fractions. The analgesic effect of the CME and its different fractions of $S$. podophyllum $\mathrm{L}$. leaves are also promising and follow dose dependent manner (i.e. supreme effect at highest dose).

\subsection{Determination of Analgesic Activity by Acetic Acid-induced Writhing Test}

The responses of mice to acetic acid induced writhing are showed in Table 2. The percentage of inhibition of writhing which is a measure of analgesic activity is presented in Fig. 2. Plant extract/fractions showed significant analgesic activity based on doses (i.e. maximum activity at maximum dose). Significant inhibition $(P<0.01)$ was observed at highest dose of $\mathrm{CME}$ with respect to remaining fractions.

\subsection{Determination of Anti-Inflammatory Activity by Carrageenan-induced Paw Edema Test}

The average volume of the paw edema and percent of inhibition of paw edema are

Table 1. Effect of methanolic extract and its fractions of $S$. podophyllum L. leaves in tail immersion test in mice

\begin{tabular}{|c|c|c|c|c|c|c|}
\hline \multirow[t]{2}{*}{ Treatment groups } & \multirow{2}{*}{$\begin{array}{l}\text { Dose } \\
\text { (mg/kg } \\
\text { b.w.) }\end{array}$} & \multirow{2}{*}{$\begin{array}{l}\text { Basal } \\
\text { reaction } \\
\text { time (sec) }\end{array}$} & \multicolumn{4}{|c|}{$\begin{array}{l}\text { Reaction time after administration of standard or } \\
\text { extract/fractions at different time interval (sec) }\end{array}$} \\
\hline & & & $30 \mathrm{~min}$ & $60 \mathrm{~min}$ & $120 \mathrm{~min}$ & $180 \mathrm{~min}$ \\
\hline $\begin{array}{l}\text { Control (Distilled } \\
\text { water) }\end{array}$ & $10 \mathrm{~mL}$ & $3.08 \pm 0.16$ & $3.17 \pm 0.12$ & $3.40 \pm 0.07$ & $3.46 \pm 0.10$ & $3.42 \pm 0.06$ \\
\hline Standard (Dic-Na) & 30 & $2.49 \pm 0.35$ & $5.37 \pm 0.13$ & $5.86 \pm 0.10$ & $6.07 \pm 0.15^{*}$ & $6.29 \pm 0.16^{* * *}$ \\
\hline \multirow[t]{3}{*}{ CME } & 50 & $3.18 \pm 0.45$ & $3.94 \pm 0.21^{*}$ & $4.25 \pm 0.35$ & $4.86 \pm 0.11$ & $5.08 \pm 0.29$ \\
\hline & 100 & $3.15 \pm 0.49$ & $4.09 \pm 0.18$ & $4.48 \pm 0.21$ & $5.10 \pm 0.42$ & $5.36 \pm 0.35^{*}$ \\
\hline & 200 & $3.10 \pm 0.45$ & $4.19 \pm 0.43$ & $4.56 \pm 0.25$ & $5.29 \pm 0.45$ & $5.49 \pm 0.41^{* * *}$ \\
\hline \multirow[t]{3}{*}{ NHF } & 50 & $3.07 \pm 0.48$ & $3.24 \pm 0.21$ & $3.55 \pm 0.14$ & $3.70 \pm 0.16$ & $3.97 \pm 0.24$ \\
\hline & 100 & $3.01 \pm 0.22$ & $3.49 \pm 0.21$ & $3.75 \pm 0.15$ & $3.85 \pm 0.17$ & $4.02 \pm 0.21$ \\
\hline & 200 & $2.91 \pm 0.14$ & $3.52 \pm 0.20$ & $3.85 \pm 0.13$ & $4.02 \pm 0.15^{*}$ & $4.20 \pm 0.22^{*}$ \\
\hline \multirow[t]{3}{*}{ CLF } & 50 & $3.25 \pm 0.24$ & $3.39 \pm 0.12$ & $3.64 \pm 0.16$ & $3.75 \pm 0.21$ & $3.77 \pm 0.12$ \\
\hline & 100 & $3.04 \pm 0.19$ & $3.42 \pm 0.23$ & $3.68 \pm 0.25$ & $3.80 \pm 0.23$ & $3.84 \pm 0.11$ \\
\hline & 200 & $2.86 \pm 0.11$ & $3.48 \pm 0.29$ & $3.75 \pm 0.34$ & $3.93 \pm 0.27$ & $4.10 \pm 0.10^{* *}$ \\
\hline \multirow[t]{3}{*}{ EAF } & 50 & $3.36 \pm 0.44$ & $3.45 \pm 0.42$ & $3.70 \pm 0.37$ & $3.77 \pm 0.42$ & $3.82 \pm 0.41$ \\
\hline & 100 & $3.28 \pm 0.38$ & $3.49 \pm 0.44$ & $3.75 \pm 0.42$ & $3.83 \pm 0.36$ & $3.89 \pm 0.39$ \\
\hline & 200 & $3.27 \pm 0.41$ & $3.50 \pm 0.45$ & $3.77 \pm 0.40$ & $3.86 \pm 0.38$ & $3.94 \pm 0.41^{*}$ \\
\hline \multirow[t]{3}{*}{ AQF } & 50 & $3.36 \pm 0.33$ & $3.51 \pm 0.30$ & $3.77 \pm 0.35$ & $3.87 \pm 0.31$ & $3.92 \pm 0.30^{*}$ \\
\hline & 100 & $3.31 \pm 0.31$ & $3.59 \pm 0.31$ & $3.90 \pm 0.29$ & $3.99 \pm 0.28 *$ & $4.02 \pm 0.27^{\star *}$ \\
\hline & 200 & $3.26 \pm 0.29$ & $3.73 \pm 0.27$ & $4.02 \pm 0.26$ & $4.15 \pm 0.17$ & $4.22 \pm 0.17^{*}$ \\
\hline
\end{tabular}




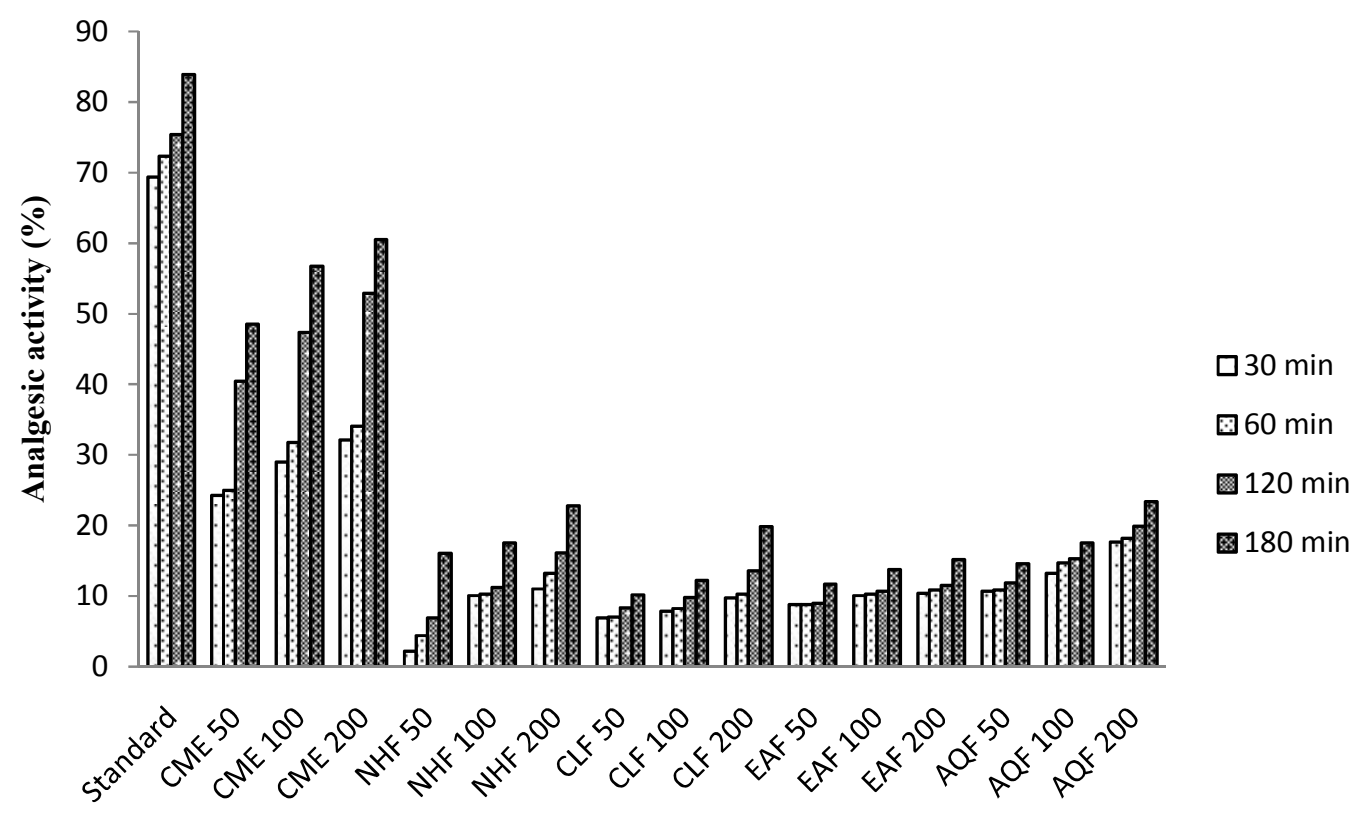

Plant extract/Fractions/Standard

Fig. 1. Percentage of analgesic effect of methanolic extract and its fractions of $S$. podophyllum L. leaves in tail immersion test in mice

Where, CME: Crude methanol extract; NHF: n-hexane fraction; EAF: Ethyl acetate fraction; CLF: Chloroform fraction; $A Q F$ : Aqueous fraction

Table 2. Effect of methanolic extract and its fractions of S. podophyllum L. leaves in acetic acid-induced writhing test in mice

\begin{tabular}{lll}
\hline Treatment groups & Dose (mg/kg b.w.) & Average number of writhing (n) \\
\hline Control (Distilled water) & $10 \mathrm{~mL}$ & $67.54 \pm 1.99$ \\
Standard (Dic-Na) & 30 & $23.69 \pm 0.93^{* *}$ \\
CME & 50 & $32.74 \pm 1.60$ \\
& 100 & $29.24 \pm 1.73$ \\
NHF & 200 & $27.30 \pm 1.34^{* *}$ \\
& 50 & $49.23 \pm 0.77$ \\
CLF & 100 & $46.19 \pm 1.07$ \\
& 200 & $43.86 \pm 1.04$ \\
EAF & 50 & $48.05 \pm 1.57$ \\
& 100 & $45.22 \pm 1.20$ \\
AQF & 200 & $42.29 \pm 1.54^{*}$ \\
& 50 & $44.51 \pm 1.11$ \\
& 100 & $41.22 \pm 1.18$ \\
& 200 & $38.18 \pm 1.10$ \\
Vat & 50 & $56.38 \pm 1.06$ \\
& 100 & $54.49 \pm 0.78^{*}$
\end{tabular}

Values were expressed as mean \pm SEM $(n=6)$. Where, CME: Crude methanol extract; NHF: $n$-hexane fraction; EAF: Ethyl acetate fraction; CLF: Chloroform fraction; $A Q F$ : Aqueous fraction. ${ }^{\star} P<0.05,{ }^{* \star} P<0.01$ significant difference from the control group

mentioned in Table 3 and Fig. 3 respectively. The injection of the carrageenan in paw created an inflammatory edema which increased gradually. Marked anti-inflammatory activity was exerted by CME $(P<0.001)$ with respect to remaining fractions. Dose dependent response (i.e. maximum effect at highest dose) was also reported in this test. 
Table 3. Effect of methanolic extract and its fractions of S. podophyllum L. leaves in carrageenan-induced paw edema test in rats

\begin{tabular}{|c|c|c|c|c|c|c|}
\hline \multirow[t]{2}{*}{ Treatment groups } & \multirow[t]{2}{*}{ Dose (mg/kg b.w.) } & \multirow{2}{*}{$\begin{array}{l}\text { Initial paw volume } \\
\text { (mm) }\end{array}$} & \multicolumn{4}{|c|}{ Volume of paw edema at different time interval (mm) } \\
\hline & & & $30 \mathrm{~min}$ & $60 \mathrm{~min}$ & $120 \mathrm{~min}$ & $180 \mathrm{~min}$ \\
\hline Control (Distilled water) & $10 \mathrm{~mL}$ & $0.3930 \pm 0.059$ & $0.3989 \pm 0.055$ & $0.4018 \pm 0.020$ & $0.4026 \pm 0.042$ & $0.4020 \pm 0.025$ \\
\hline Standard (Ind) & 10 & $0.3590 \pm 0.013$ & $0.3602 \pm 0.032$ & $0.3614 \pm 0.028$ & $0.3621 \pm 0.027^{* *}$ & $0.3611 \pm 0.027^{* * *}$ \\
\hline \multirow[t]{3}{*}{ CME } & 50 & $0.3941 \pm 0.009$ & $0.3971 \pm 0.011$ & $0.3988 \pm 0.011$ & $0.4005 \pm 0.009$ & $0.4005 \pm 0.009$ \\
\hline & 100 & $0.3651 \pm 0.019$ & $0.3679 \pm 0.019$ & $0.3688 \pm 0.021$ & $0.3695 \pm 0.020$ & $0.3687 \pm 0.014^{*}$ \\
\hline & 200 & $0.3142 \pm 0.008$ & $0.3162 \pm 0.008$ & $0.3170 \pm 0.005$ & $0.3177 \pm 0.004$ & $0.3168 \pm 0.004^{\star * *}$ \\
\hline \multirow[t]{3}{*}{ NHF } & 50 & $0.4101 \pm 0.006$ & $0.4149 \pm 0.009$ & $0.4160 \pm 0.008$ & $0.4169 \pm 0.007$ & $0.4160 \pm 0.008$ \\
\hline & 100 & $0.4023 \pm 0.005$ & $0.4068 \pm 0.007$ & $0.4079 \pm 0.006$ & $0.4088 \pm 0.005$ & $0.4080 \pm 0.005$ \\
\hline & 200 & $0.4053 \pm 0.008$ & $0.4094 \pm 0.005$ & $0.4103 \pm 0.006$ & $0.4112 \pm 0.007$ & $0.4106 \pm 0.007$ \\
\hline \multirow[t]{3}{*}{ CLF } & 50 & $0.4191 \pm 0.004$ & $0.4232 \pm 0.005$ & $0.4243 \pm 0.004^{*}$ & $0.4251 \pm 0.004$ & $0.4242 \pm 0.004^{*}$ \\
\hline & 100 & $0.4213 \pm 0.004$ & $0.4254 \pm 0.005$ & $0.4263 \pm 0.003$ & $0.4272 \pm 0.003$ & $0.4265 \pm 0.005^{\star *}$ \\
\hline & 200 & $0.4097 \pm 0.002$ & $0.4137 \pm 0.004$ & $0.4145 \pm 0.003$ & $0.4154 \pm 0.010$ & $0.4148 \pm 0.009$ \\
\hline \multirow[t]{3}{*}{ EAF } & 50 & $0.3941 \pm 0.003$ & $0.3982 \pm 0.006$ & $0.3993 \pm 0.003$ & $0.4001 \pm 0.002$ & $0.3992 \pm 0.011$ \\
\hline & 100 & $0.4073 \pm 0.004$ & $0.4112 \pm 0.003$ & $0.4123 \pm 0.012$ & $0.4133 \pm 0.007$ & $0.4124 \pm 0.008$ \\
\hline & 200 & $0.4105 \pm 0.003$ & $0.4135 \pm 0.006$ & $0.4145 \pm 0.005$ & $0.4156 \pm 0.005$ & $0.4148 \pm 0.007$ \\
\hline \multirow[t]{3}{*}{ AQF } & 50 & $0.3281 \pm 0.003$ & $0.3328 \pm 0.003$ & $0.3338 \pm 0.003$ & $0.3342 \pm 0.007$ & $0.3343 \pm 0.007$ \\
\hline & 100 & $0.3811 \pm 0.003$ & $0.3856 \pm 0.004$ & $0.3860 \pm 0.004$ & $0.3871 \pm 0.006$ & $0.3871 \pm 0.006$ \\
\hline & 200 & $0.3516 \pm 0.017$ & $0.3555 \pm 0.010$ & $0.3565 \pm 0.008$ & $0.3578 \pm 0.007$ & $0.3570 \pm 0.006^{*}$ \\
\hline
\end{tabular}

Values expressed as mean \pm SEM $(n=6)$. Where, CME: Crude methanol extract; NHF: $n$-hexane fraction; EAF: Ethyl acetate fraction; CLF: Chloroform fraction; AQF: 


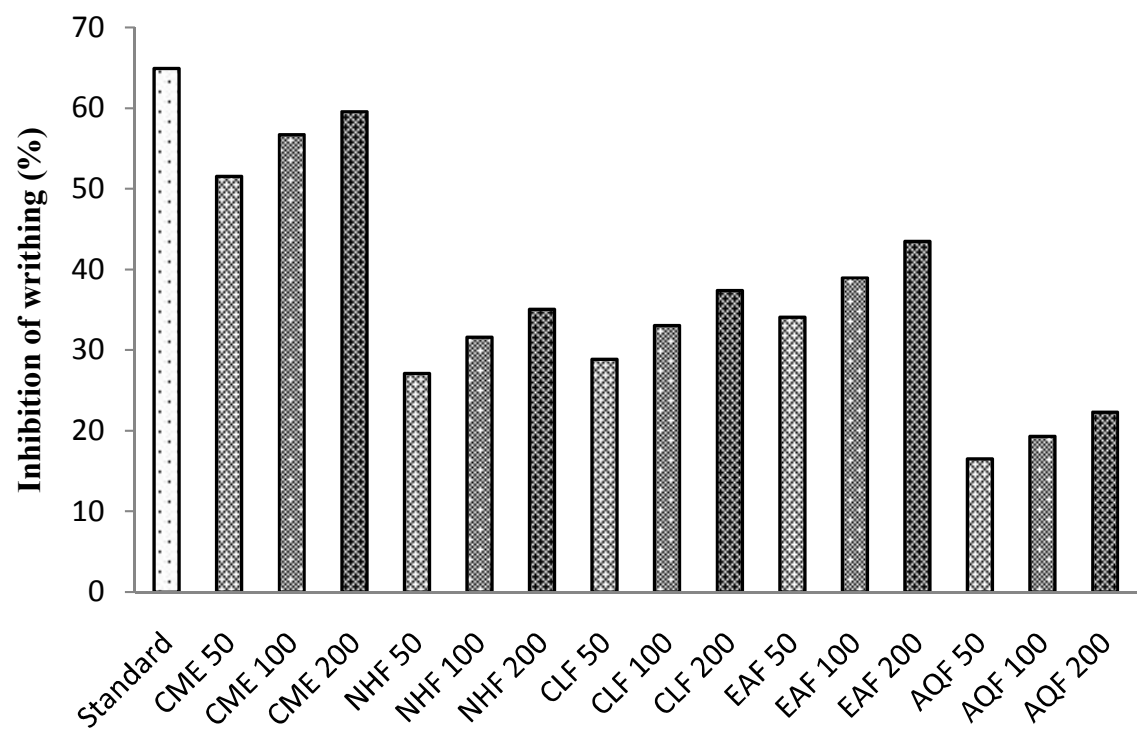

Plant extract/Fractions/Standard

Fig. 2. Percentage of analgesic effect of methanolic extract and its fractions of S. podophyllum L. leaves in acetic acid-induced writhing test in mice

Where, CME: Crude methanol extract; NHF: n-hexane fraction; EAF: Ethyl acetate fraction; CLF: Chloroform fraction; $A Q F$ : Aqueous fraction

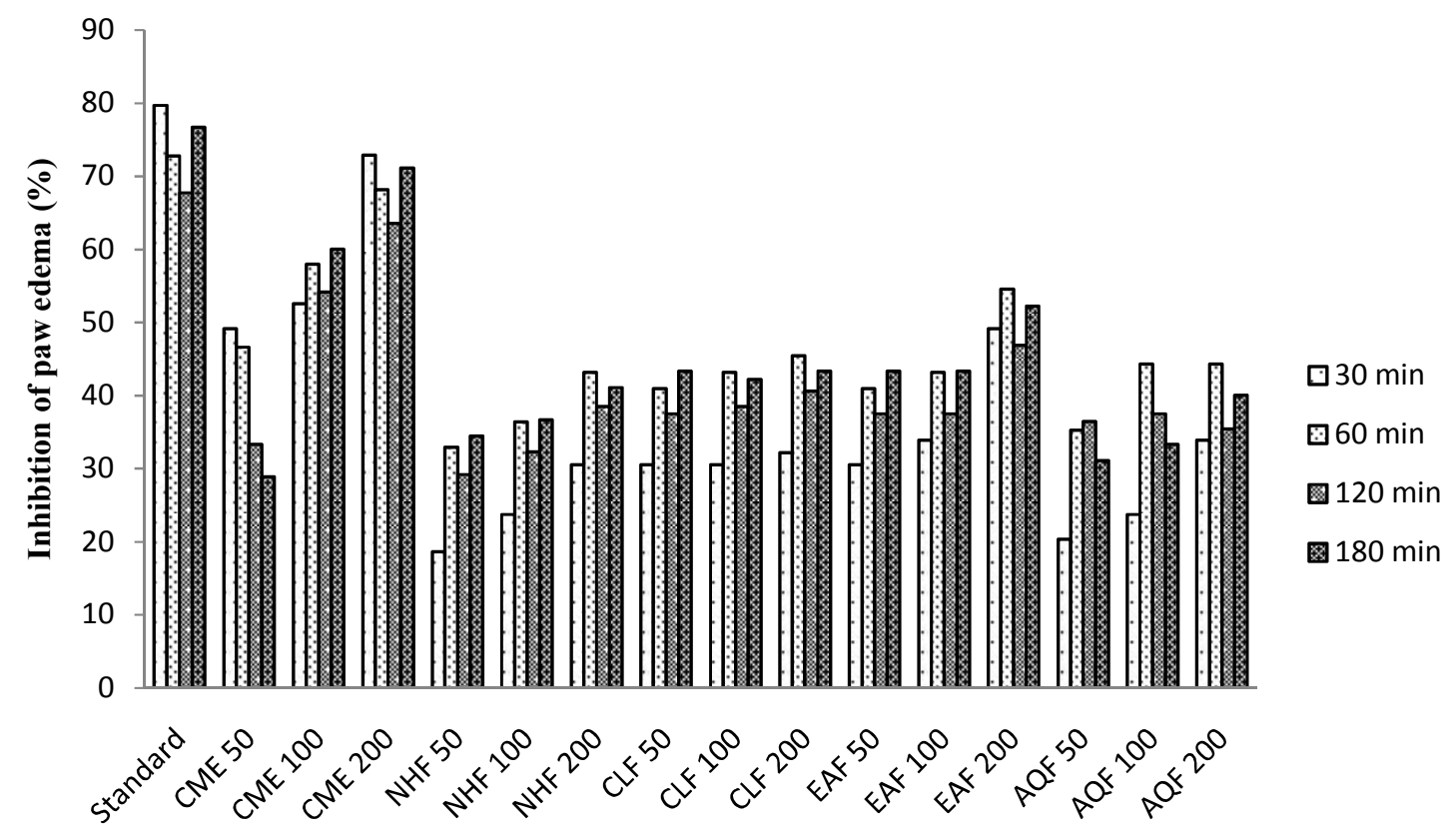

Plant extract/Fractions/Standard

Fig. 3. Percentage of anti-inflammatory effect of methanolic extract and its fractions of $S$. podophyllum $\mathrm{L}$. leaves in carrageenan-induced paw edema test in rats

Where, CME: Crude methanol extract; NHF: n-hexane fraction; EAF: Ethyl acetate fraction; CLF: Chloroform fraction; $A Q F$ : Aqueous fraction 


\section{DISCUSSION}

Natural products mainly plants have been used from ancient civilization in human medicine as therapeutic agents $[37,38]$. Natural compounds have been described to interface with different molecular and cellular targets such as hormone, transmembrane transporters, enzymes and neurotransmitter receptors $[39,40]$. Present work describes the analgesic and anti-inflammatory effects of methanolic extract and its fractions of S. podophyllum L. leaf.

The analgesic activity of the extract was determined by tail immersion method and acetic acid induced writhing test using Dic-Na as standard. Tail immersion method was used for evaluating centrally acting analgesic effects of drugs exert action through opioid receptor is highly correlated with relief of human pain [41]. An increased in pain threshold indicate analgesic activity [42]. In this test, maximum protection $(P<0.001)$ was observed in $180 \mathrm{~min}$ at highest dose of CME compared to other fractions. In the study of analgesic activities of Xanthosoma sagittifolium L. researchers reported notable activity [43]. On the other hand, acetic acid is an irritating agent used in writhing test. The acetic acid induced writing test is effective but it is non-selective [44]. It is a sensitive method to evaluate peripherally acting analgesics and represents pain sensation by triggering localized inflammatory response [45]. Such pain stimulus causes allow leaving of free arachidonic acid from the tissue phospholipid [46]. In response to pain due to irritation signals are transmitted to central nervous system and causes release of mediators such as prostaglandins which contributes to the increased sensitivity to nociceptors [47]. In this test highest inhibition $(P<0.01)$ was observed at highest dose of CME compared to other fraction. An earlier study on analgesic activity of Buddleja crispa Benth. similarly stated hopeful activity [48].

For determination of anti-inflammatory activity carrageenan-induced edema test was used in which Ind was used as standard. In this test, various types of mediators such as histamine, serotonin, and increased synthesis and release of prostaglandins are responsible for the inflammatory effect of carrageenan model [49]. Carrageenan produces acute inflammation believed to be biphasic; the early phase (1-2 hrs after carrageenan injection), in which the edema production is mediated by histamine and serotonin and the late phase (after $2^{\text {nd }}$ hrs) the vascular permeability is maintained by bradykinin and prostaglandins [50]. These mediators contribute in the inflammatory response and induce pain [51]. It has been shown that the second phase of carrageenan-induced edema is sensitive to clinically used anti-inflammatory drugs and commonly employed to assess the antiphlogistic effect of the natural products $[52,53]$. In this test, $\mathrm{CME}$ at the highest dose exhibited highest $(P<0.001)$ anti-inflammatory activity compared to other fraction after carrageenan induction. A previous study in the study of anti-inflammatory activity of Leucas cephalotes Roxb. also reported similar results [54].

This study exposed an effective in vivo analgesic and anti-inflammatory actions of $S$. podophyllum $\mathrm{L}$. leaves, which may be a potent natural source of therapeutic agents for the management of algesia and inflammation.

\section{CONCLUSION}

In conclusion, the findings of this study established promising analgesic and antiinflammatory activities of $S$. podophyllum $L$. leaves. We have seen that $\mathrm{CME}$ of $S$. podophyllum L. leaves has high potentiality rather than all fractions in case of all experiments. This study demonstrated scientific rationale for the folk use of this plant as the analgesic and anti-inflammatory actions. Therefore, additional research will be suggested to discover the auspicious phytoconstituent(s).

\section{CONSENT}

It is not applicable.

\section{ETHICAL APPROVAL}

The protocol of the experiment was approved by the animal ethics committee of the Department of Pharmacy, Southeast University, Dhaka, Bangladesh. The animals care and health were maintained according to the guidelines of $\mathrm{NIH}$.

\section{ACKNOWLEDGEMENTS}

The authors are grateful to the Department of Pharmacy, Southeast University, Dhaka, Bangladesh for providing research facilities. The authors wish to thank the anonymous reviewer(s)/editor(s) of this article for their constructive reviews. 


\section{COMPETING INTERESTS}

The authors declare that they have no competing interests.

\section{REFERENCES}

1. Thirupathi $T$, Kabeer $A$, Meenakshi $P$, Navya G, Ashwini K, Manisha B, et al. Analgesic activity of the ethanolic extract of flower parts of Celosia argentea linn. Wor $\mathrm{J}$ Pharma Res. 2017,6(5):775-780.

2. Craig AD. Pain mechanisms: Labeled lines versus convergence in central processing. Annu Rev Neurosci. 2003;26(1):1-30.

3. Kumar $\mathrm{KH}$, Elavarasi P. Definition of pain and classification of pain disorders. J Adv Cli Res Ins. 2016,3:87-90.

4. Dubin AE, Patapoutian, A. Nociceptors: The sensors of the pain pathway. $\mathrm{J}$ Clin Invest. 2010;120(11):3760-3772.

5. Mantri P, Witiak DT. Inhibition of cyclooxygenase and 5-lipoxygenase. Curr Med Chem. 1994;1:328-355.

6. Mittal M, Siddiqui MR, Tran K, Reddy SP, Malik AB. Reactive oxygen species in inflammation and tissue injury. Antioxid Redox Signal. 2014;20(7):1126-1167.

7. Amran MS, Uddin MS. Pharmakon comprehensive pharmaceutical pharmacology. $1^{\text {st }}$ ed. Dhaka: Krishnachura Prokashoni; 2014.

8. Arleevskaya MI, Kravtsova OA, Lemerle J, Renaudineau Y, Tsibulkin AP. How rheumatoid arthritis can result from provocation of the immune system by microorganisms and viruses. Front Microbiol. 2016;7:1296.

9. Al-Saeed A. Gastrointestinal and cardiovascular risk of nonsteroidal antiinflammatory drugs. Oma Med J. 2011; 26(6):385-391.

10. Rahman A, Haque A, Uddin MS, Mian MM, Sufian MA, Rahman MM, et al. In vitro screening for antioxidant and anticholinesterase effects of Uvaria littoralis Blume.: A nootropic phytotherapeutic remedy. Intellect Disabl Diagn J. 2017;5(2):50-60.

11. Uddin MS, Nasrullah M, Hossain MS, Rahman MM, Sarwar MS, Amran MS, et al. Evaluation of nootropic activity of Persicaria flaccida on cognitive performance, brain antioxidant markers and acetylcholinesterase activity in rats: Implication for the management of
Alzheimer's disease. Am J Psychiatry Neurosci. 2016;4(2):26-37.

12. Hasan MF, Iqbal MA, Uddin MS. Antibacterial and antifungal activity of Litsea monopetala leaves on selected pathogenic strains. European J. Med. Plants. 2016;12(4):1-8.

13. Mamun AA, Hossain M, Islam A, Zaman S, Uddin MS. Asparagus racemosus Linn. potentiate the hypolipidemic and hepatoprotective activity of fenofibrate in alloxan-induced diabetic rats. Plant. 2017; 5(5-1):1-12.

14. Rahman MM, Uddin MS, Nejum MR, Al Din SM, Uddin GS. Study on antibacterial activity of Cajanus cajan L. against coliforms isolated from industrial waste water in Bangladesh. Plant. 2017;5(5-1): 13-18.

15. Uddin MS, Mamun AA, Hossain MS, Akter F, lqbal MA, Asaduzzaman M. Exploring the effect of Phyllanthus emblica L. on cognitive performance, brain antioxidant markers and acetylcholinesterase activity in rats: Promising natural gift for the mitigation of alzheimer's disease. Ann Neurosci. 2016;23(4):218-29.

16. Gupta SS. Propects and perpectives of normal plants products in medicine. Indian J Pharmacol. 1994;26(1):1-12.

17. Baker JT, Borris RP, Carte B, Cordell GA, Soejarto DD, et al. Natural product drug discovery and development: New perspectives on international collaboration. J Nat Prod. 1995;58(9):1325-1357.

18. Uddin MS, Mamun AA, Sarwar MS, Chaity $\mathrm{NH}$, Haque A, Akter N, et al. Medicine that causes memory loss: Risk of neurocognitive disorders. Int Neuropsychiatr Dis J. 2016;8(1):1-8.

19. Ekor $M$. The growing use of herbal medicines: Issues relating to adverse reactions and challenges in monitoring safety. Front Pharmacol. 2013;4:177.

20. Smith WL, De Witt DL. Biochemistry of prostaglandins endoperoxide $\mathrm{H}$ synthase-1 and synthase-2 and their differential susceptibility to NSAIDs. Semin. Nephrol. 1995;15:179-194.

21. Uddin MS, Uddin GMS, Begum MM, Begum Y, Herrera-Calderon O, Islam MI, et al. Inspection of phytochemical content and in vitro antioxidant profile of Gnaphalium luteoalbum L.: An unexplored phytomedicine. J Pharma Nutriti Sci. 2017; 7(3):136-146. 
22. Uddin MS, Mamun AA, Hossain MS, Ashaduzzaman M, Noor MAA, Hossain MS, et al. Neuroprotective effect of Phyllanthus acidus $\mathrm{L}$. on learning and memory impairment in a scopolamineinduced animal model of dementia and oxidative stress: Natural wonder for regulating the development and progression of Alzheimer's disease. Adv Alzheimer Dis. 2016;5(2):53-72.

23. Dias DA, Urban S, Roessner U. A historical overview of natural products in drug discovery. Metabolit. 2012;2(4):303336.

24. Zeraati $F$, Araghchian M, Esna-ashari F, Fazlian MM, Torabian S, Fallah $\mathrm{N}$, et al. Antinociceptive properties of ascorbic acid: Evidence for the mechanism of action. Avi J Med Bioche. 2014;2(1):e18572.

25. Farshchi A, Ghiasi G, Khatabi PM, Farzaee $H$, Niayesh A. Antinociceptive effect of promethazine in mice. Iran J Basic Med Sci. 2009;12(3-4):140-145.

26. Hossain MS, Uddin MS, Moniruzzaman M, Asaduzzaman M. Comparative study of cytotoxic potential and phytochemical screening of Xanthosoma sagittifolium rhizome and Syngonium podophylam leaf. J Med Plant Res. 2015;3(3):43-46.

27. Hernandez J. In Hawaiian rainforests: Exotic aroid ecologies. Aroideana. 2007; 30:91-97.

28. Cabi.org. Syngonium podophyllum (arrowhead vine); 2016.

Available:http://www.cabi.org/isc/datasheet $\underline{152285}$

(Accessed: May 20, 2017)

29. Sosa S, Balick MJ, Arvigo R, Esposito RG, Pizza C, Altinier G, et al. Screening of the topical anti-inflammatory activity of some Central American plants. J. Ethnopharmacol. 2002;81(2):211-215.

30. Camporese A, Balick MJ, Arvigo R, Esposito RG, Morsellinom N, De Simone $F$, et al. Screening of anti-bacterial activity of medicinal plants from Belize (Central America). J Ethnopharmacol. 2003;87(1): 103-7.

31. Kupchan SM, Karim A, Marcks C. Taxodione and taxodone, two novel diterpenoid quinone methide tumor inhibitors from Taxodium distichum. J Org Chem. 1968;90(21):5923-4.

32. National Research Council. Guide for the care and use of laboratory animals. $8^{\text {th }} \mathrm{ed}$. Washington, D.C: National Academies Press; 2011.
33. Organisation for Economic cooperation and Development. OECD guidelines for the testing of chemicals: Acute oral toxicity-acute toxic class method. Paris: OECD Environment, Health and Safety Publications; 2002.

34. Aydin S, Demir T, Ozturk $\mathrm{Y}$, Başer $\mathrm{KH}$. Analgesic activity of Nepeta italic L. Phytother Res. 1999;13:20-3.

35. Koster R, Anderson M, Beer JD. Acetic acid for analgesic screening. Fed Proceed. 1959;18:412-7.

36. Winter CA, Risley EA, Nuss GW. Carrageenan-induced oedema in hind paw of the rat as an assay for antiinflammatory drugs. Proc Soc Exp Biol Med. 1962;111: 544-7.

37. Uddin MS, Mamun A, Khanum S, Begum $\mathrm{Y}$, Alam MS. Analysis of in vitro antioxidant activity of Caryota urens L. leaves: A traditional natural remedy. J Coast Life Med. 2016;4(6):483-484.

38. Uddin MS, Asaduzzaman M, Mamun AA, lqbal MA, Wahid F. Neuroprotective activity of Asparagus racemosus Linn. against ethanol-induced cognitive impairment and oxidative stress in rats brain: auspicious for controlling the risk of alzheimer's disease. J Alzheim Dis Parkinsoni. 2016;6(4):1-10.

39. Harborne JB. Twenty-five years of chemical ecology. Nat Prod Rep. 2001; 18(4):361-379.

40. Hussain SA, Sulaiman AA, Alhaddad $H$, Alhadidi Q. Natural polyphenols: Influence on membrane transporters. J Int Ethnopharma. 2016;5(1):97-104.

41. Woode E, Abotsi WKM. Antinociceptive effect of an ethanolic extract of the aerial parts of Hilleria latifolia (Lam.) H. Walt. (Phytolaccaceae). J Pharm Bioallied Sci. 2011;3(3):384-396.

42. Kaushik D, Kumar A, Kaushik P, Rana AC. Analgesic and anti- inflammatory activity of Pinus roxburghii sarg. Adv Pharmacol Sci. 2012;6.

43. Hossain MS, Uddin MS, Asaduzzaman M, Munira MS, Uddin MJ, Rafe MR, et al. Inquiry of analgesic and anti-inlfammatory activities of Xanthosoma sagittifolium L.: An effective medicinal plant. J Coast Life Med. 2017;5(1):22-26.

44. Gawade SP. Acetic acid induced painful endogenous infliction in writhing test on mice. J. Pharmaco. Pharmacothera. 2012; 3(4):348. 
45. Khatun $\mathrm{H}$, Majumder $\mathrm{R}$, Mamun $\mathrm{A}$, Alam EK, Jami SI, Alam B. Preliminary pharmacological activity of the methanolic extract of Premna integrifolia barks in rats. Avi J Med Bioche. 2014;4(3):215224.

46. Ribeiro RA, Vale ML, Thomazzi SM, Paschoalato AB, Poole S, Ferreira SH, et al. Involvement of resident macrophages and mast cells in the writhing nociceptive response induced by zymosan and acetic acid in mice. Eur J Pharmacol. 2000;387: 111-118.

47. Zeraati $F$, Araghchian M, Esna-ashari F, Fazlian MM, Torabian S, Fallah $\mathrm{N}$, et al. Antinociceptive properties of ascorbic acid: Evidence for the mechanism of action. Avi J Med Bioche. 2014;2(1):1-9.

48. Bukhari IA, Gilani AH, Meo SA, Saeed A. Analgesic, anti-inflammatory and antiplatelet activities of Buddleja crispa. BMC Complement Altern Med. 2016;16:79.

49. Jothi S, Vetriselvan S, Gayathiri S, Ishwin S, Shereenjeet G, Devi HC, et al. Comparative evaluation of antiinflammatory activity of extract of Curcuma longa and standard drug in carrageenan induced paw edema model using albino wistar rats. Int J Biolo Pharma Res. 2012; 3(4):538-544.

50. Burch RM, DeHaas C. A bardykinin antagonist inhibits carrageenan edema in rats. Naunyn Schmiedebergs Arch Pharmacol. 1990;342:189-93.

51. Di Rosa M, Sorrentino L, Parente L. Nonsteroidal anti-inflammatory drugs and leucocyte emigration. J Pharm Pharmacol. 1972;24(7):575-7.

52. Toma W, Gracioso JS, Hiruma-Lima CA, Andrade FD, Vilegas W, Souza Brito AR. Evaluation of the analgesic and antiedematogenic activities of Quassia amara bark extracts. J Ethnopharmacol. 2003;85: 19-23.

53. Mesia-Vela S, Souccar C, Lima-Landman MT, Lapa AJ. Pharmacological study of Stachytarpheta cayennensis Vahl in rodents. Phytomed. 2004;11:616-24.

54. Sufian MA, Islam MR, Chowdhury TK, Rahman A, Uddin MS, Koly SF, et al. Investigation of in vivo analgesic, antiinflammatory, in vitro membrane stabilizing and thrombolytic activities of Atylosia scarabaeoides and Crotalaria spectabilis leaves. J Pharmaco Toxico. 2017;12(3): 111-119.

(c) 2017 Hossain et al.; This is an Open Access article distributed under the terms of the Creative Commons Attribution License (http://creativecommons.org/licenses/by/4.0), which permits unrestricted use, distribution, and reproduction in any medium, provided the original work is properly cited.

Peer-review history:

The peer review history for this paper can be accessed here: http://sciencedomain.org/review-history/20787 